\title{
A sesquiterpene quinone, dysidine, from the sponge Dysidea villosa, activates the insulin pathway through inhibition of PTPases
}

\author{
Yu ZHANG*, Yan LI", Yue-wei GUO*, Hua-liang JIANG, Xu SHEN* \\ Drug Discovery and Design Centre, State Key Laboratory of Drug Research, Shanghai Institute of Materia Medica, Chinese Academy of Sciences, Shanghai \\ 210203, China
}

\begin{abstract}
Aim: The sesquiterpene hydroquinones/quinones belong to one class of marine sponge metabolites, and they have received considerable attention due to their varied biological activities, including anti-tumor, anti-HIV, and anti-inflammatory action. In order to probe the potential anti-diabetic effect of the sesquiterpene hydroquinones/quinones, the effect of dysidine on the insulin pathway was studied.

Methods: The promotion of glucose uptake by dysidine was studied in differentiated 3T3-L1 cells. The increase in membrane-located GLUT4 by dysidine was studied in CHO-K1/GLUT4 and 3T3-L1 cells by immuno-staining. The activation of the insulin signaling pathway by dysidine was probed by Western blotting. The inhibition of PTPases by dysidine was detected in vitro.

Results: Dysidine, found in the Hainan sponge Dysidea villosa in the Chinese South Sea, effectively activated the insulin signaling pathway, greatly promoted glucose uptake in 3T3-L1 cells, and showed strong insulin-sensitizing activities. The potential targets of action for dysidine were probed, and the results indicated that dysidine exhibited its cellular effects through activation of the insulin pathway, possibly through the inhibition of protein tyrosine phosphatases, with more specific inhibition against protein tyrosine phosphatase 1B (PTP1B).

Conclusion: Our findings are expected to expand understanding of the biological activities of sesquiterpene hydroquinones/quinones, and they show that dysidine could be a potential lead compound in the development of an alternative adjuvant in insulin therapy.
\end{abstract}

Keywords: sesquiterpene quinone; dysidine; PTP1B; inhibitor; insulin Acta Pharmacologica Sinica (2009) 30: 333-345; doi: 10.1038/aps .2009.5

\section{Introduction}

The marine sponge has served as an attractive resource for drug lead compound discovery because of the structural novelty and diversity of its secondary metabolites. To date, a great number of constituents isolated from marine sponges have been discovered to have various bioactivities, including anti-tumor ${ }^{[1-3]}$, anti-HIV ${ }^{[4]}$, and anti-inflammatory actions $^{[5-7]}$. Some compounds and analogues have been approved for clinical use, such as cytarabine $(\text { Ara-C })^{[8]}$.

\# These two authors contributed equally.

* Correspondence to Prof Xu SHEN and Prof Yue-wei GUO.

E-mail xshen@mail.shcnc.ac.cn (Xu SHEN),ywguo@mail.shcnc. ac.cn (Yue-wei GUO)

Received 2008-11-05 Accepted 2009-01-07
Sesquiterpene hydroquinones/quinones belong to one class of marine sponge metabolites, and they have received considerable attention for their abundant structural variants and numerous biological activities. For example, avarol and avarone have been studied extensively since the 1980s due to their ability to efficiently inhibit HIV replication in vitro by inhibiting HIV reverse transcriptase ${ }^{[4]}$. Moreover, bolinaquinone, dysidenones, and dysidine exhibit a potent anti-inflammatory effect through inhibition of secretory phospholipase $\mathrm{A}_{2}\left(\mathrm{PLA}_{2}\right)$ and 5-lipoxygenase activity ${ }^{[5,6]}$. To date, much has been published concerning the sesquiterpenes' anti-tumor effects. It has been reported that this class of compounds inhibits tumor cells through multiple mechanisms, including inducing DNA damage ${ }^{[1]}$, blocking tubulin assembly ${ }^{[2]}$, and inhibiting protein kinases ${ }^{[3]}$. However, few related biological 
activities in the control of metabolic syndrome have been reported.

Diabetes mellitus is a syndrome characterized by abnormally high blood sugar. Impaired ability to remove glucose from the circulation in response to insulin in peripheral tissues is considered one of the main causes of type 2 diabetes $^{[9-11]}$. Glucose transporter 4 (GLUT4) is the principal glucose transporter in muscle and fat tissue, and its translocation to the membrane is regulated mainly by the insulin signaling pathway. Insulin initiates the signaling pathway by activating the insulin receptor (IR), leading to tyrosine phosphorylation of insulin receptor substrates (IRSs) and subsequently recruiting phosphatidylinositol 3-kinase (PI3K). PI3K mediates AKT activation by generating phosphatidylinositol-3,4,5-trisphosphate (PIP3), which recruits AKT to the plasma membrane. The activated AKT stimulates the downstream pathway and finally stimulates glucose transport by translocating the key intracellular GLUT4 vesicles to the plasma membrane ${ }^{[12,13]}$.

Protein tyrosine phosphatase 1B (PTP1B) was demonstrated to negatively regulate the insulin pathway via inactivation of IR and IRS1 ${ }^{[14-16]}$. Recently, the leptin pathway was also found to be regulated by PTP1B, in which the neuronal PTP1B binds and dephosphorylates JAK2, which was downstream of the leptin receptor, and subsequently inhibited leptin signaling ${ }^{[17,18]}$. PTP1B has been identified as an attractive target for the discovery of type 2 diabetes agents. The most exciting evidence came from PTP1B knock-out mice, which showed super-sensitivity to insulin and resistance to dietinduced type 2 diabetes ${ }^{[19,20]}$. Moreover, treatment of ob/ob and $\mathrm{db} / \mathrm{db}$ mice with PTP1B-specific antisense oligonucleotides in the liver and fat tissue resulted in normalization of glucose levels ${ }^{[21]}$. This kind of antisense oligonucleotide has already entered phase II clinical trails ${ }^{[22]}$. However, due to poor bioavailability and the complicated delivery approach of these antisense drugs, developing small molecular PTP1B inhibitors is still considered a more effective and convenient way to improve insulin sensitivity for diabetic patients. A number of PTP1B inhibitors have been discovered to exhibit significant improvement of insulin sensitivity and reduction of blood glucose in preclinical insulin-resistance mouse $\operatorname{model}^{[23,24]}$.

Glucose uptake is the rate-limiting step in the disposal of blood glucose. The impaired ability of peripheral organs (adipose tissue and muscle) to remove blood glucose due to insulin resistance is the main cause of type 2 diabetes. Insulin resistance in adipose tissue can also cause impairments in lipid and glucose homeostasis of the whole body, so improving insulin sensitivity in adipocytes is one of the efficient approaches in the treatment of diabetes ${ }^{[25]}$. In the current study, the most representative adipocyte cell line, 3T3-L1, was thus adopted for evaluating the glucose uptake effect of dysidine, and the potential acting targets for dysidine were probed.

\section{Materials and methods}

Materials Dysidine was isolated from the Hainan sponge Dysidea villosa with a purity $>99.5 \%$. Insulin, pNitrophenyl phosphate ( $p \mathrm{NPP})$, cytochalasin $\mathrm{B}, 2$-deoxy- $D$-glucose, biotin, methylisobutylxanthine $p$-benzoquinone, and dexamethasone were purchased from Sigma-Aldrich. Pantothenic acid calcium salt was from Eastman. Sodium orthovanadate and compound-2 were obtained from Calbiochem (Merck Biosciences, Cat № 539741), and 2-[ $\left.{ }^{3} \mathrm{H}\right]$-deoxy- $D$-glucose was from Perkin Elmer. All cell culture reagents were bought from GIBCO. Hoechst 33342, Alexa Fluor 647 goat antimouse IgG, Alexa Fluor 488 goat anti-rabbit IgG and Lipofectamine ${ }^{\mathrm{TM}} 2000$ were from Invitrogen. All antibodies were purchased from Cell Signaling Technology except antiGAPDH antibody (KangChen, China), anti-myc antibody (Tiangen Biotech, China), and anti-GLUT4 antibody (Santa Cruz). 3T3-L1 adipocytes were kindly provided by Prof Yan CHEN (Institute of Nutritional Sciences, Shanghai, China). The CHO-K1/GLUT4 stable cell line was described previously ${ }^{[26]}$. The In Cell Analyzer Instrument was from GE Healthcare. The 96-well plate reader was purchased from Bio-Rad Laboratories. The scintillation counter was from Perkin Elmer. The Leica TCS confocal microscope was obtained from Leica.

Isolation of dysidine The lyophilized sponge $D$ villosa (dry weight $51.2 \mathrm{~g}$ ) was exhaustively extracted with acetone. The acetone extract was partitioned consecutively between $\mathrm{H}_{2} \mathrm{O}$ and $\mathrm{Et}_{2} \mathrm{O}, \mathrm{H}_{2} \mathrm{O}$ and $n-\mathrm{BuOH}$. The $n-\mathrm{BuOH}$-soluble portion was purified by Sephadex LH-20 column chromatography to yield dysidine ( $21.1 \mathrm{mg}, 0.041 \%$ dry weight).

Plasmid construction pGEX4T-1-PTP1B was constructed according to the method previously reported ${ }^{[26]}$. The coding sequence of the TC-PTP catalytic domain (aa 1-288) was amplified by PCR from a TC45 vector that was kindly provided by Prof Nicholas K TONKS (Cold Spring Harbor Laboratory, NY, USA). The PCR product was digested with BamHI and EcoRI and ligated into a pGEX4T-1 vector. pGEX2T-CD45 (aa 560-1256) was kindly donated by Prof Rafael PULIDO (Centro de Investigación Príncipe Felipe, Valencia 46013, Spain).

Preparation of GST-tagged PTP-fusion proteins The expression of GST-tagged PTP-fusion proteins was carried 
out according to the instructions from Amersham Pharmacia with some modifications. pGEX2T-CD45, pGEX4T-TCPTP and pGEX4T-PTP1B vectors were each transformed into BL21 (DE3), respectively. The transformants were grown at $37^{\circ} \mathrm{C}$ in $\mathrm{LB}$ medium supplemented with ampicillin $(100 \mu \mathrm{g} / \mathrm{mL})$. Bacterial cultures were diluted with fresh LB medium (plus $100 \mu \mathrm{g} / \mathrm{mL}$ ampicillin) at a ratio of $1: 100$ and incubated at $37^{\circ} \mathrm{C}$ for $4 \mathrm{~h}$. After another 4 -h induction with isopropyl- $\beta$ - $D$-thiogalactopyranoside (IPTG) at suitable temperature $\left(22^{\circ} \mathrm{C}\right.$ for GST-TC-PTP and GST-CD 45 , and $37^{\circ} \mathrm{C}$ for GST-PTP1B), the bacterial cultures were collected and frozen at $-80^{\circ} \mathrm{C}$.

Purifications of GST-tagged proteins, including GSTPTP1B, GST-TC-PTP, and GST-CD45, were carried out according to the manufacturer's instructions (Amersham Pharmacia).

Enzymatic activity assays The enzymatic activities of Recombinant PTPs were measured at $25^{\circ} \mathrm{C}$ using $p N P P$ as the substrate. The initial velocities of the enzymatic reactions were determined by continuously measuring the absorbance at $405 \mathrm{~nm}$ every $15 \mathrm{~s}$ using a microplate spectrophotometer (Bio-Rad). During the evaluation of the $\mathrm{IC}_{50}$ value, PTPs $(0.3 \mu \mathrm{mol} / \mathrm{L})$ were incubated with compounds in reaction buffer (50 mmol/L HEPES, pH 5.0, $1 \mathrm{mmol} / \mathrm{L}$ EDTA, and $100 \mathrm{mmol} / \mathrm{L} \mathrm{NaCl}$ ) for $10 \mathrm{~min}$, and the reactions were initiated by the addition of $p$ NPP $(5 \mathrm{mmol} / \mathrm{L})$. During the determination of slow-binding inhibition type, compounds were incubated with $p$ NPP $(5 \mathrm{mmol} / \mathrm{L})$ in reaction buffer $(50$ $\mathrm{mmol} / \mathrm{L}$ HEPES, pH 5.0, $1 \mathrm{mmol} / \mathrm{L}$ EDTA, and $100 \mathrm{mmol} /$ $\mathrm{L} \mathrm{NaCl}$ ) for $10 \mathrm{~min}$, and reactions were initiated by addition of PTP1B $(0.3 \mu \mathrm{mol} / \mathrm{L})$. In the identification of reversibility, PTP1B $(1 \mu \mathrm{mol} / \mathrm{L})$ was incubated with excess dysidine $(150 \mu \mathrm{mol} / \mathrm{L})$ in reaction buffer $(50 \mathrm{mmol} / \mathrm{L}$ HEPES, $\mathrm{pH}$ $5.0,1 \mathrm{mmol} / \mathrm{L}$ EDTA, and $100 \mathrm{mmol} / \mathrm{L} \mathrm{NaCl}$ ) for $2 \mathrm{~h}$, and aliquots of the mixture were then withdrawn and rapidly diluted into the above reaction buffer containing $5 \mathrm{mmol} /$ $\mathrm{L} p \mathrm{NPP}$ at a dilution ratio of 1:20. In an effort to explore whether dysidine was active-site directed, PTP1B $(0.3 \mu \mathrm{mol} /$ $\mathrm{L})$ was added to a reaction system that contained a fixed concentration of dysidine $(10 \mu \mathrm{mol} / \mathrm{L})$ and varied concentrations of $p$ NPP $(0.5-10 \mathrm{mmol} / \mathrm{L})$. The progress curves were obtained by continuously monitoring the absorbance at 405 $\mathrm{nm}$, and the $K_{\mathrm{obs}}$ values were obtained by fitting individual progress curves to the equation: $[\mathrm{P}]=V_{s} t+\left[\left(V_{\mathrm{i}}-V_{\mathrm{s}}\right) / K_{\mathrm{obs}}\right]$ $\left[1-\exp \left(-K_{o b s} t\right)\right]$. The relationship between $K_{\mathrm{obs}}$ and substrate $(p \mathrm{NPP})$ was fitted according to equation: $K_{\mathrm{obs}}=K_{\max } /$ $\left(1+[p \mathrm{NPP}] / K_{\mathrm{M}}\right)^{[27]}$. To investigate the effects of catalase or DTT on the inhibition by dysidine (or $p$-benzoquinone as a positive control), PTP1B $(0.3 \mu \mathrm{mol} / \mathrm{L})$ was incubated with dysidine $(10 \mu \mathrm{mol} / \mathrm{L})$ or $p$-benzoquinone $(10 \mu \mathrm{mol} / \mathrm{L})$ in reaction buffer ( $50 \mathrm{mmol} / \mathrm{L}$ HEPES, pH 5.0, $1 \mathrm{mmol} / \mathrm{L}$ EDTA, and $100 \mathrm{mmol} / \mathrm{L} \mathrm{NaCl}$ ) containing catalase (1000 $\mathrm{U} / \mathrm{mL}$ ), DTT ( $5 \mathrm{mmol} / \mathrm{L})$, or neither, for $10 \mathrm{~min}$. Then, $p$ NPP $(5 \mathrm{mmol} / \mathrm{L})$ was added to initiate the reactions. For the determination of the $\mathrm{IC}_{50}$ values of dysidine and $p$-benzoquinone in the presence of DTT, PTPs $(0.3 \mu \mathrm{mol} / \mathrm{L})$ were incubated with compounds in reaction buffer $(50 \mathrm{mmol} / \mathrm{L}$ HEPES, pH 5.0, $1 \mathrm{mmol} / \mathrm{L}$ EDTA, $100 \mathrm{mmol} / \mathrm{L} \mathrm{NaCl}$ and 5 $\mathrm{mmol} / \mathrm{L} \mathrm{DTT} \mathrm{or} \mathrm{no} \mathrm{DTT)} \mathrm{for} 10 \mathrm{~min}$, and the reactions were initiated by the addition of $p \operatorname{NPP}(5 \mathrm{mmol} / \mathrm{L})$.

Cell culture and differentiation $\mathrm{CHO}-\mathrm{K} 1$ cells and CHO-K1/GLUT4 cells were maintained in F-12 Ham medium with Glutamax, supplemented with $10 \%$ fetal bovine serum (FBS), and penicillin-streptomycin $(50 \mathrm{U} / \mathrm{mL})$. 3T3-L1 cells were cultured in DMEM supplemented with $10 \% \mathrm{FBS}$, penicillin-streptomycin, biotin ( 8 $\mathrm{mg} / \mathrm{L})$, and pantothenic acid calcium salt $(4 \mathrm{mg} / \mathrm{L})$. All the cells were cultured at $37^{\circ} \mathrm{C}$ in a humidified atmosphere with $5 \% \mathrm{CO}_{2}$. The differentiation procedure of 3T3-L1 followed the classic method. Briefly, two days after $100 \%$ confluence, cells were stimulated with MDI cocktail $[115 \mathrm{mg} / \mathrm{L}$ methylisobutylxanthine (MIX), $0.39 \mathrm{mg} / \mathrm{L}$ dexamethasone and $1 \mathrm{mg} / \mathrm{L}$ insulin] for $3 \mathrm{~d}$, and the medium was then changed with fresh medium containing $1 \mathrm{mg} / \mathrm{L}$ insulin for another 3 days. The glucose uptake experiments were performed at the 8th day after MDI cocktail stimulation.

Western blot The phosphorylations of IR, AKT, p38 MAPK, GSK $3 \alpha / \beta$, and ERK1/2 were investigated by Western blot using anti-phospho-IR (Tyr1150/1151), anti phospho-AKT (Ser473), anti-phospho-GSK3 $\alpha / \beta$ (Ser21/9), anti-phospho p38 MAPK (Thr180/Tyr182), and antiERK1/2 (Thr202/Tyr204) primary antibodies, and HRPconjugated secondary antibodies. GAPDH was used as a loading control. Each experiment was repeated three times, and densitometry analysis of bands was performed using Photoshop. Following the general method for similar data analysis $^{[28]}$, a paired Student's $t$-test was performed to determine the statistical significance (significance considered at $P<0.05, P<0.01)$

GLUT4-membrane translocation assay in CHO-K1/ GLUT4 cells CHO-K1/GLUT4 cells were seeded into 96-well black plates. After the cell density reached $100 \%$, F12 medium was changed to 3T3-L1 medium for $2 \mathrm{~d}^{[29]}$. Cells were stimulated with insulin for 5 min after an 8-h serum starvation, fixed with $3.7 \%$ formaldehyde for $15 \mathrm{~min}$, and labeled with anti-myc monoclonal antibody and secondary antibody (Alexa Fluor 647 conjuncted anti-mouse antibody). In the whole process, since no detergent was added, 
the antibodies could only access the myc epitope present on the cell membranes. Fluorescence pictures were obtained by the In Cell Analyzer 1000 Instrument (GE Healthcare) with the same exposure time. Membrane-located GLUT4 was represented by the intensity of the red fluorescence (Alex fluor 647) and normalized by the intensity of the green fluorescence (GLUT4-EGFP), which represented total GLUT4 ${ }^{[30]}$. As has been reported elsewhere ${ }^{[31]}$, a paired Student's $t$-test was performed to determine the statistical significance (significance considered at $P<0.05, P<0.01$ ), and, unless indicated, $n=6$.

2- $\left[{ }^{3} \mathrm{H}\right]$-Deoxy-glucose uptake in 3T3-L1 adipocytes The 2- $\left[{ }^{3} \mathrm{H}\right]$-deoxy-D-glucose uptake assay was performed in fully differentiated 3T3-L1 cells (on the 8th day since MDI stimulation). During the assay, cells were incubated in serum-free medium containing $0.5 \%$ BSA for $4 \mathrm{~h}$, and then in Krebs buffer for another $30 \mathrm{~min}$. For the last $5 \mathrm{~min}$, cells were incubated with 2 - $\left[{ }^{3} \mathrm{H}\right]$-deoxy-D-glucose. The uptake was stopped by addition of ice-cold PBS. Then the cells were lysed in $0.1 \%$ Triton $(100 \mu \mathrm{L} /$ well $)$. Finally, the radioactivity was calculated by a scintillation counter (Perkin Elemer). Cytochalasin B was used to measure nonspecific binding, and the value was subtracted from all the data. Referring to the statistical analysis of similar data ${ }^{[32]}$, a paired Student's $t$-test was performed to determine the statistical significance, $(n=3$, significant difference at $P<0.05, P<0.01)$.

Immunocytochemistry and confocal microscopy The distribution of endogenous GLUT4 in 3T3-L1 cells was studied by immunocytochemistry ${ }^{[33]}$. Fully differentiated 3T3-L1 cells (on the 8th day since MDI stimulation) were treated with trypsin and plated onto coverslips. Serumstarved 3T3-L1 cells were stimulated with insulin (17 $\mathrm{nmol} / \mathrm{L})$ for $30 \mathrm{~min}$ or dysidine $(20 \mu \mathrm{mol} / \mathrm{L})$ for $2 \mathrm{~h}$, and the cells were then fixed with $4 \%$ paraformaldehyde at $37^{\circ} \mathrm{C}$ for $15 \mathrm{~min}$ and washed with phosphate-buffered saline (PBS) three times. The cell membranes were permeabilized with $0.2 \%$ triton X-100 in PBS for 5 min, followed by three washes with PBS. After incubation with 3\% BSA for $15 \mathrm{~min}$, the cells were immunostained with anti-GLUT4 antibody (1:50) for $1 \mathrm{~h}$ and subsequently with Alexa Fluor 488-labeled antirabbit secondary antibody for $1 \mathrm{~h}$ at room temperature. The nucleus was stained with Hoechst 33342 for $30 \mathrm{~min}$. The coverslips were mounted, and images were taken using a Leica TCS confocal microscope (Leica, Deerfield, IL).

\section{Results}

Dysidine promotes glucose uptake in 3T3-L 1 adipocytes The effect of dysidine (Figure 1A) on glu- cose uptake in fully differentiated 3T3-L1 adipocytes was investigated. As shown in Figure 1B, dysidine greatly increased glucose uptake in 3T3-L1 cells, and the potency of dysidine at $20 \mu \mathrm{mol} / \mathrm{L}$ was almost the same as that of insulin $(17 \mathrm{nmol} / \mathrm{L})$ and was superior to compound-2 $(20 \mu \mathrm{mol} / \mathrm{L})$, which was used as a positive control.

A<smiles>CC1=CCCC2[C@@H](C)[C@](C)(CC3=C(O)C(=O)C=C(NCCS(=O)(=O)O)C3=O)CC[C@]12C</smiles>

B

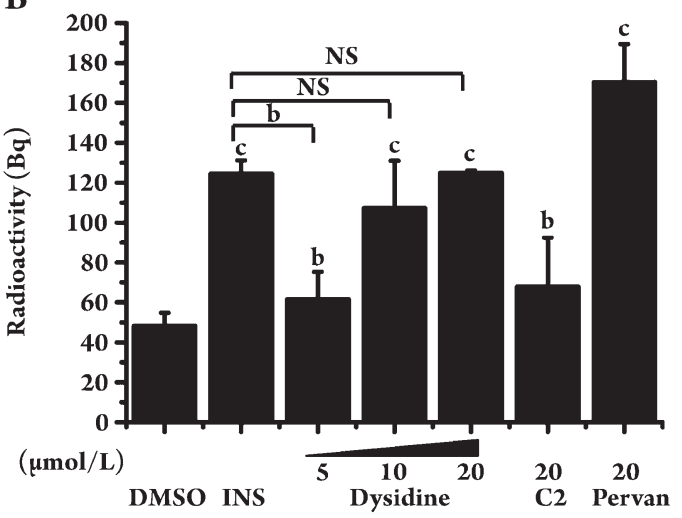

Figure 1. Dysidine greatly increased glucose uptake in 3T3L1 adipocytes. (A) The chemical structure of dysidine. (B) Fully differentiated 3T3-L1 cells were incubated with indicated concentrations of dysidine $(2 \mathrm{~h})$, compound-2 (C2, $20 \mu \mathrm{mol} / \mathrm{L}, 2 \mathrm{~h})$, pervanadate (Pervan, $20 \mu \mathrm{mol} / \mathrm{L}, 0.5 \mathrm{~h}$ ), or insulin (INS, $17 \mathrm{nmol} / \mathrm{L}$, $0.5 \mathrm{~h}$ ). Within the last $5 \mathrm{~min}$, cells were incubated with $2-\left[{ }^{3} \mathrm{H}\right]$-deoxy$D$-glucose. Glucose uptake was terminated by ice-cold PBS. Cells were lysed in $0.1 \%$ Triton X-100 and the radioactivity was calculated by a scintillation counter. ${ }^{b} P<0.05,{ }^{c} P<0.01$ vs DMSO treated cells unless indicated. $n=3$. NS: no significant difference.

Dysidine increases membrane translocation of GLUT4 in 3T3-L1 cells Since GLUT4 is the principal glucose transporter in 3T3-L1 cells, the effect of dysidine on the membrane translocation of GLUT4 was investigated. In the assay, after incubation of dysidine $(20 \mu \mathrm{mol} / \mathrm{L})$ for $2 \mathrm{~h}$, or insulin $(17 \mathrm{nmol} / \mathrm{L})$ for $5 \mathrm{~min}$, the distribution of endogenous GLUT4 in 3T3-L1 cells was studied by immunocytochemistry. GLUT4 was found to be distributed mainly in the cytoplasm in DMSO-treated cells, but after stimulation by either dysidine or insulin, there was an obvious increase in membrane-located GLUT4 observed (Figure 2A, Arrow). As the amount of membrane-located GLUT4 is hard to 
quantify in the assay, a CHO-K1/GLUT4 stable cell line was used to study the effect of dysidine on GLUT4 translocation in a quantitative manner ${ }^{[26,29]}$. The detailed method for mea- surement of membrane-located GLUT4 is described in the "Materials and Methods" section. In this model, dysidine $(20 \mu \mathrm{mol} / \mathrm{L})$ and insulin $(170 \mathrm{nmol} / \mathrm{L})$ effectively increased
A
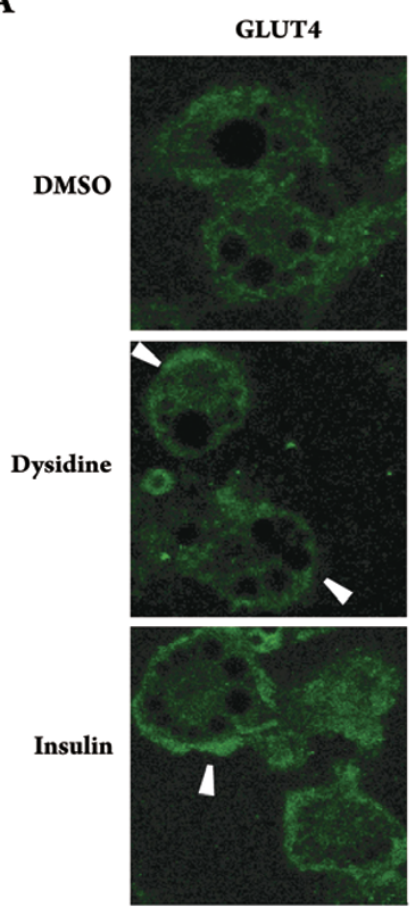
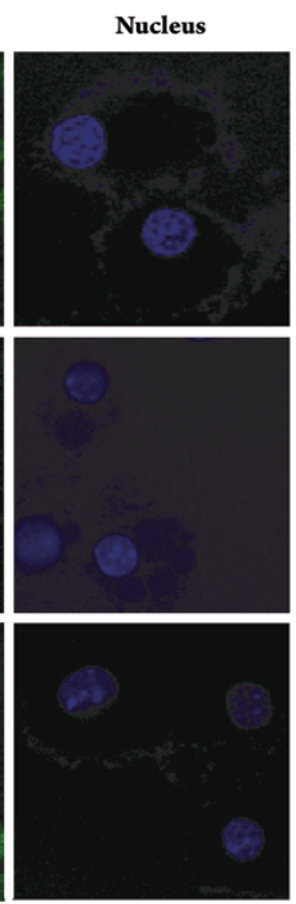
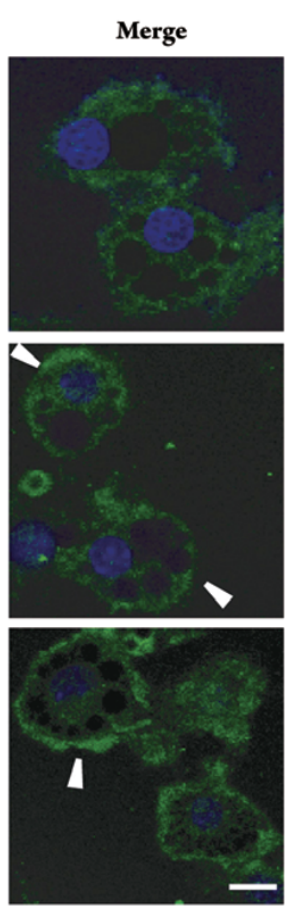

B
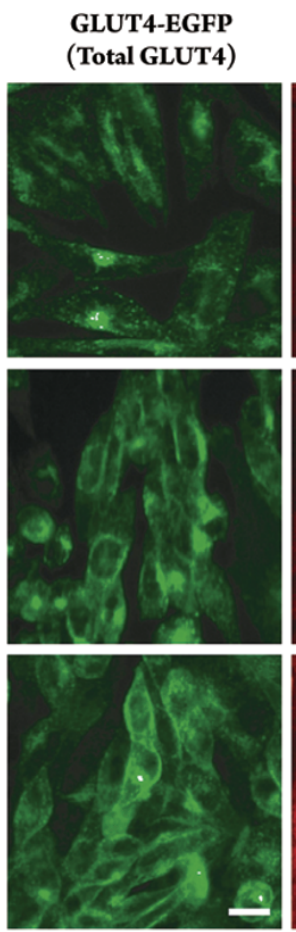

Alexa fluor 647 (Membrane GLUT4)
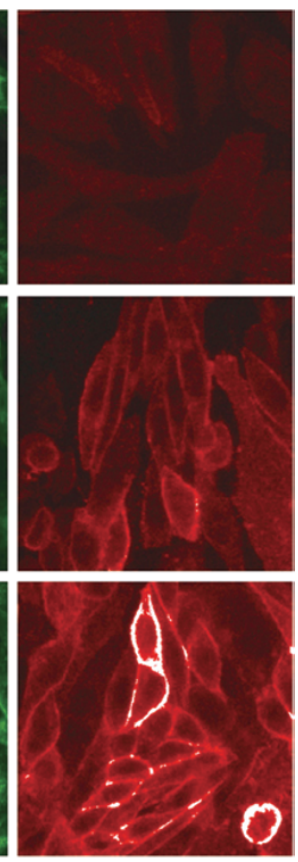
C e
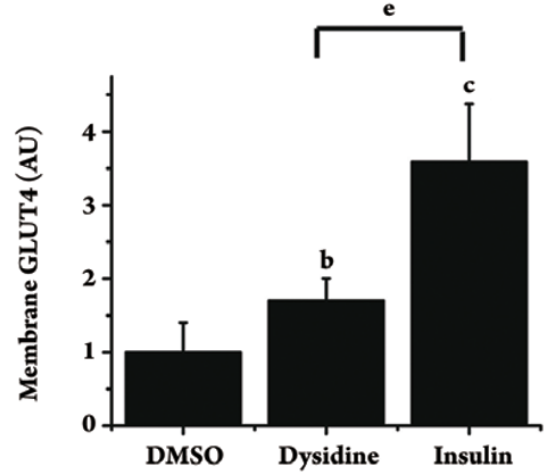

Figure 2. Dysidine promoted GLUT4 translocation in 3T3-L1 and CHO-K1/GLUT4 cells. (A) Distribution of endogenous GLUT4 in resting, dysidine, or insulin stimulated 3T3-L1 cells. Fully differentiated 3T3-L1 cells were starved and stimulated with either dysidine (20 $\mu \mathrm{mol} / \mathrm{L}, 2 \mathrm{~h})$ or insulin $(17 \mathrm{nmol} / \mathrm{L}, 30 \mathrm{~min})$. The endogenous GLUT4 was then visualized by immunostaining. Membrane located GLUT4 is indicated with an arrow. Scale bar, $10 \mu \mathrm{m}$. (B) Distribution of GLUT4-EGFP in resting, dysidine stimulated, or insulin stimulated CHO-K1/GLUT4 cells. Serumstarved CHO-K1/GLUT4 cells were stimulated with dysidine $(20 \mu \mathrm{mol} / \mathrm{L})$ for $2 \mathrm{~h}$, or insulin $(170 \mathrm{nmol} / \mathrm{L})$ for 5 min. Cells were fixed with $3.7 \%$ formaldehyde and labeled with anti-myc monoclonal antibody and secondary antibody (Alexa Fluor 647 conjuncted anti-mouse antibody) subsequently. In the whole process, since no detergent was added, the antibodies could only access the myc epitope on cell membranes. The green fluorescence represents total exogenous GLUT4, and the red represents membrane-located GLUT4, indicated by an arrow. Scale bar, $10 \mu \mathrm{m}$. (C) Quantitative analysis of GLUT4-membrane translocation in CHO-K1/GLUT4 cells induced by dysidine or insulin. Cells were immuno-stained as described above. Fluorescence pictures were obtained with an In Cell Analyzer 1000 Instrument (GE healthcare) with the same exposure time. Membrane-located GLUT4 was represented by the intensity of red fluorescence (Alex fluor 647) and normalized by the intensity of green fluorescence (GLUT4-EGFP), which represented total GLUT4. The membrane-located GLUT4 level of untreated cells is represented as "1". AU, artificial unit. ${ }^{\mathrm{b}} \mathrm{P}<0.05,{ }^{\mathrm{c}} \mathrm{P}<0.01$ vs DMSO treated cells unless indicated. ${ }^{\mathrm{e}} \mathrm{P}<0.05$ vs dysidine treated cells unless indicated. $n=6$. 
the membrane-located GLUT4 by $70 \%$ and $250 \%$, respectively (Figures $2 \mathrm{~B}$ and $2 \mathrm{C}$ ), matching the result from the 3T3-L1 cells.

Dysidine activates the insulin signaling pathway in 3T3-L1 and CHO-K1 cells Considering the fact that GLUT4 translocation is mainly regulated by the insulin signaling pathway in $3 \mathrm{~T} 3-\mathrm{L} 1 \mathrm{cell}^{[12,13]}$, we next investigated the possible regulation of dysidine on the insulin receptor and the relevant downstream signaling. In the assay, 3T3-L1 cells were serum-starved for $2 \mathrm{~h}$ and then incubated with dysidine (5-20 $\mu \mathrm{mol} / \mathrm{L}$ ) for $2 \mathrm{~h}$. Insulin, pervanadate (a PTP paninhibitor), and compound-2 (a specific PTP1B inhibitor) were used as positive controls. As shown in Figure 3A, dysidine increased the tyrosine phosphorylation of IR in a dose- dependent manner. The phosphorylation of the downstream kinase AKT was also increased (Figure 3B), while the total protein levels of IR and AKT were not influenced. Interestingly, dysidine also promoted the phosphorylation of $\mathrm{p} 38$ MAPK, whereas insulin had no obvious effect (Figure 3C).

We also investigated the effect of dysidine alone on insulin signaling in $\mathrm{CHO}-\mathrm{K} 1$ cells. Consistent with the above results in 3T3-L1 cells, dysidine alone activated the phosphorylation of IR and AKT in CHO-K1 cells (Figure 4). In addition, GSK $3 \alpha / \beta$ and ErK1 $/ 2$, which are located downstream of the insulin signaling pathway, were also activated by dysidine. Therefore, the results in 3T3-L1 and CHO-K1 cells suggest that dysidine initiated the proximal insulin signal transduction events and subsequently activated the
A
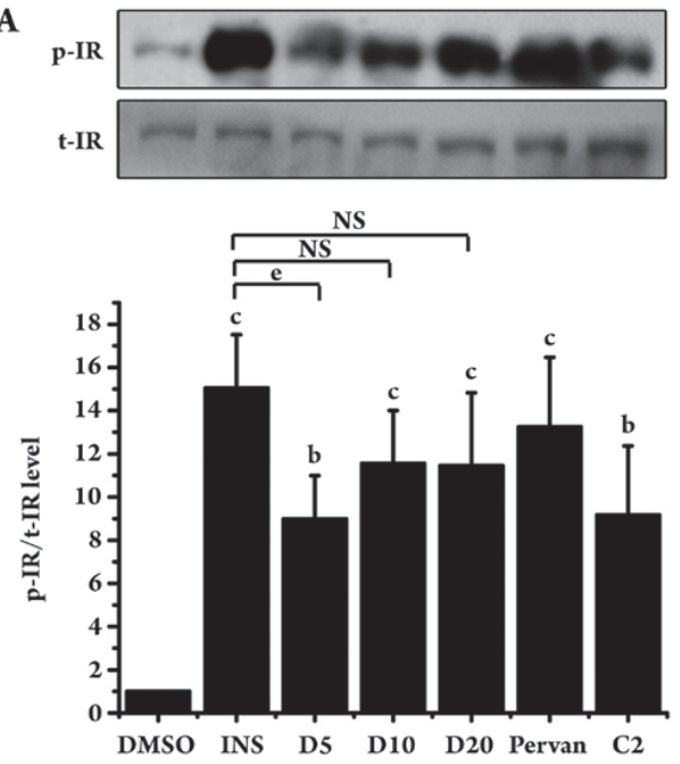

C
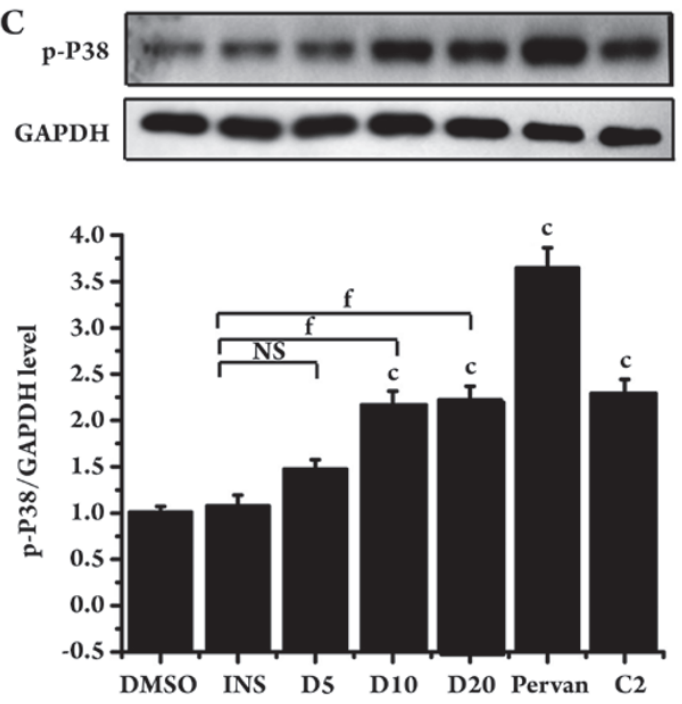

B
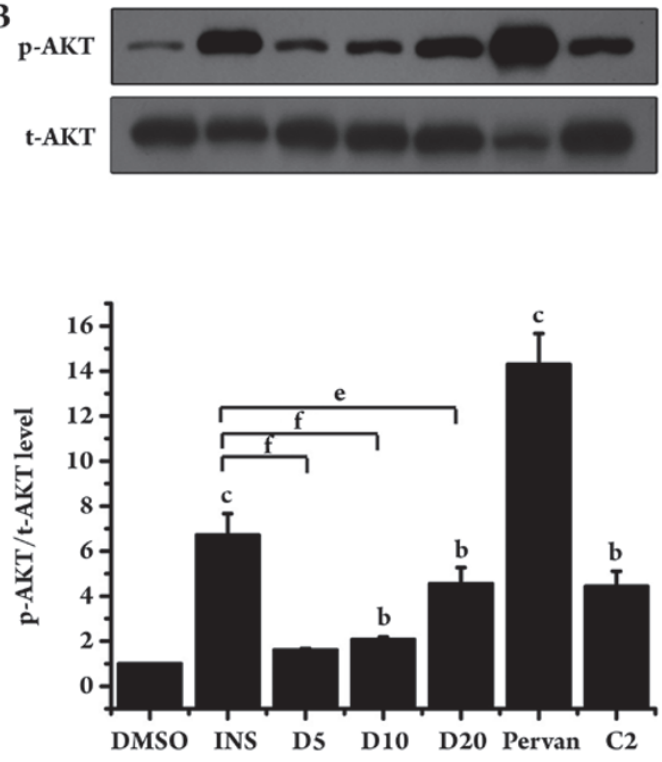

Figure 3. Dysidine activated the insulin signaling pathway in $3 \mathrm{~T} 3-\mathrm{L} 1$ cells. After being starved for $4 \mathrm{~h}$, fully differentiated 3T3-L1 cells were incubated for $2 \mathrm{~h}$ with indicated concentrations of dysidine (D5, D10, and D20 represent dysidine 5, 10, and $20 \mu \mathrm{mol} / \mathrm{L}$, respectively), or compound-2 (C2, $20 \mu \mathrm{mol} / \mathrm{L})$, or were stimulated for half of an hour with insulin (INS, $17 \mathrm{nmol} / \mathrm{L}$ ) or pervanadate (pervan, $20 \mu \mathrm{mol} / \mathrm{L}$ ). Cells were lysed on ice. The phosphorylation levels and total protein levels of IR (A) and AKT (B) were detected by Western blotting. The phosphorylation level of p38 MAPK (C) was also detected, and GAPDH was used as a loading control. The representative blots were shown in the upper panel and the bottom panel showed the relative quantitation mean \pm SD. $n=3 .{ }^{b} P<0.05,{ }^{c} P<0.01$ vs DMSO treated cells unless indicated. ${ }^{\mathrm{e}} P<0.05,{ }^{\mathrm{f}} \mathrm{P}<0.01$ vs INS treated cells unless indicated. NS: no significant difference. 
A
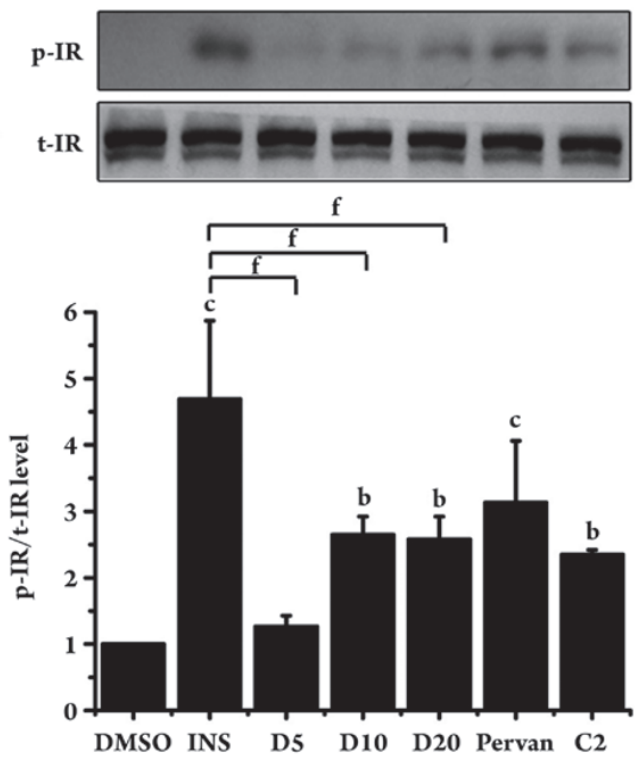

C
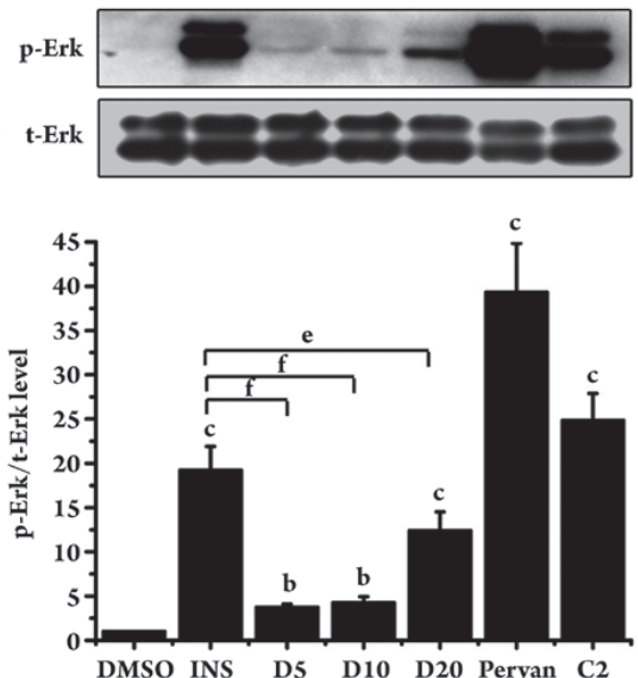

B
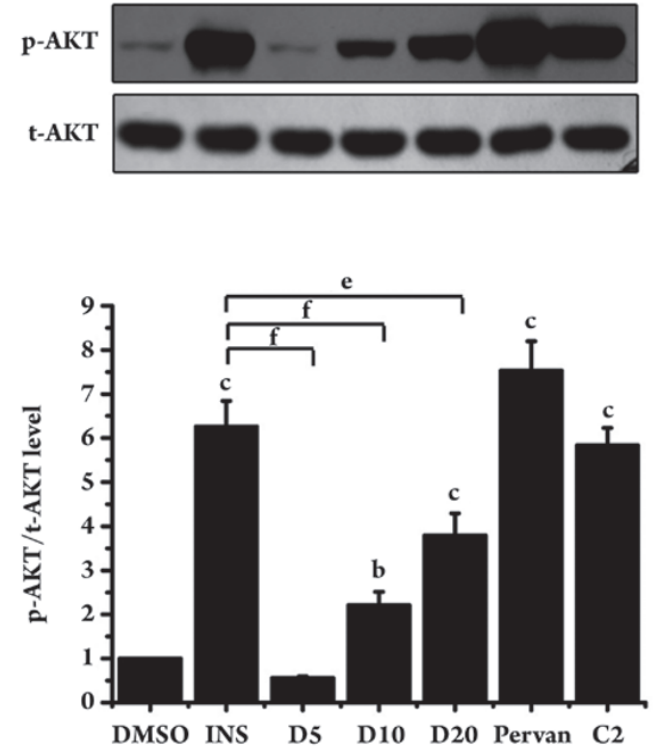

D p-GSK3

GAPDH
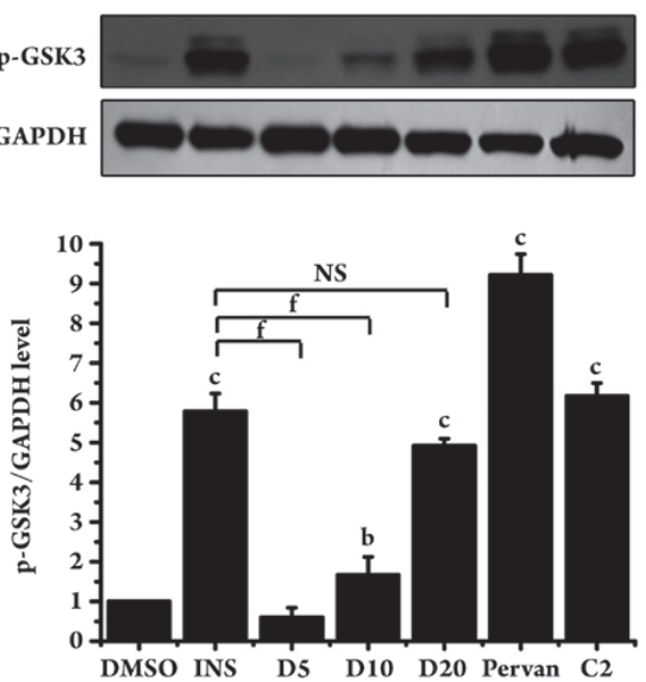

Figure 4. Dysidine activated insulin signaling pathway in CHO-K1 cells. Serum-starved CHO-K1 cells were incubated with the indicated concentrations of dysidine (D5, D10, and D20 represent dysidine 5, 10, and $20 \mu \mathrm{mol} / \mathrm{L}$, respectively) or compound-2 (C2, $20 \mu \mathrm{mol} / \mathrm{L}$ ) for $2 \mathrm{~h}$, or stimulated with insulin (INS, $170 \mathrm{nmol} / \mathrm{L}$ ) or pervanadate (pervan, $20 \mu \mathrm{mol} / \mathrm{L}$ ) for $30 \mathrm{~min}$. Cells were lysed on ice. The phosphorylation levels and total protein levels of IR (A), AKT (B), Erk1/2 (C), and GSK3 $\alpha / \beta$ (D) were detected by Western blotting. The representative blots are shown in the upper panel, and the bottom panel shows the relative quantitation mean \pm SD. $n=3 .{ }^{b} P<0.05,{ }^{c} P<0.01 v s$ DMSO treated cells unless indicated. ${ }^{\mathrm{e}} \mathrm{P}<0.05,{ }_{\mathrm{f}}^{\mathrm{P}}<0.01$ vs INS treated cells unless indicated. NS: no significant difference.

downstream signaling pathway.

Dysidine improved insulin sensitivity in CHO-K1 cells The insulin sensitizing effect of dysidine was probed in CHO-K1 cells. Serum-starved CHO-K1 cells were incubated with dysidine $(5-20 \mu \mathrm{mol} / \mathrm{L})$ for $2 \mathrm{~h}$ and then stimulated with insulin $(50 \mathrm{nmol} / \mathrm{L})$ for $5 \mathrm{~min}$, using compound-2 and pervanadate as positive controls. As shown in Figure 5A, dysidine enhanced insulin-stimulated phosphorylation of AKT. We further explored the effect of dysidine on GLUT4membrane translocation in CHO-K1/GLUT4 stable cells. As indicated in Figure 5B, CHO-K1/GLUT4 cells exhibited an effective response to insulin stimulation as indicated by the increase in membrane-bound GLUT4 after insulin treatment $(50 \mathrm{nmol} / \mathrm{L}, 5 \mathrm{~min})$. Moreover, dysidine further 
$\mathbf{A}$

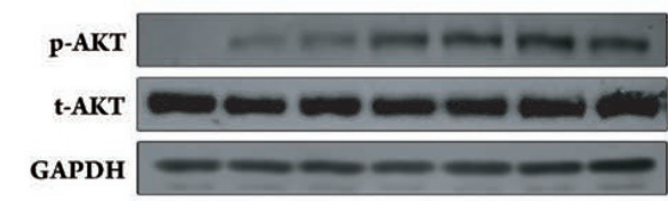

b

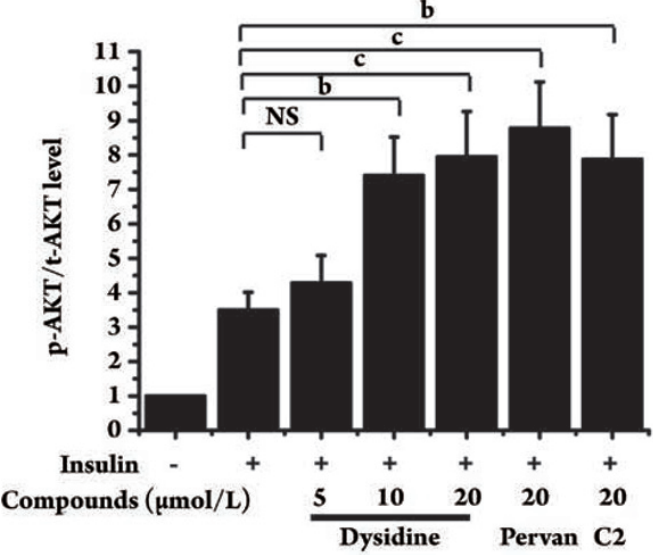

B

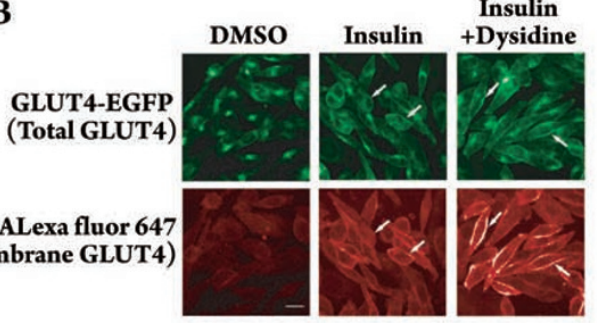

C

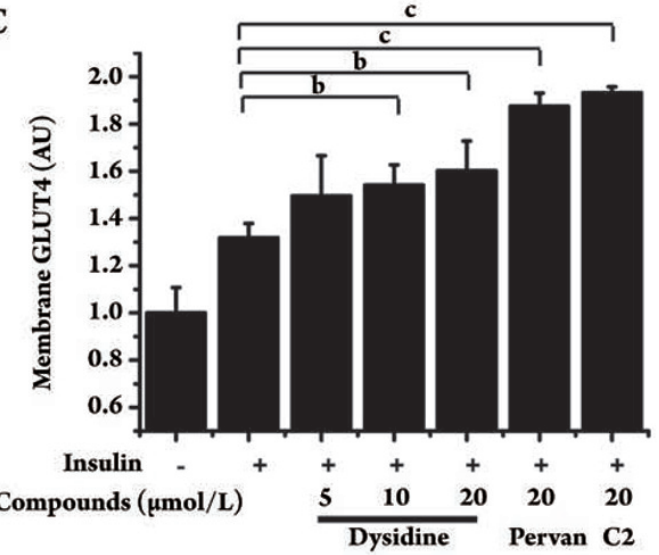

Figure 5. Dysidine enhanced insulin-stimulated AKT phosphorylation and membrane translocation of exogenous GLUT4 in CHO-K1 cells. (A) The increase of insulin-stimulated AKT phosphorylation by dysidine is shown. Serum-starved CHO-K1 cells were incubated with the indicated concentration of dysidine, compound $-2(\mathrm{C} 2,20 \mu \mathrm{mol} / \mathrm{L})$ or pervanadate (pervan, $20 \mu \mathrm{mol} / \mathrm{L})$ for $2 \mathrm{~h}$, and then stimulated with insulin $(50 \mathrm{nmol} / \mathrm{L}$ ) for $5 \mathrm{~min}$. Cells were lysed on ice. The phosphorylation levels and total protein levels of AKT were detected by Western blotting, The representative blots were shown in the upper panel and the bottom panel showed the relative quantitation mean \pm SD. $n=3$. ${ }^{\mathrm{b}} P<0.05,{ }^{\mathrm{c}} P<0.01 v s$ control, NS: no significant difference. (B) Distribution of GLUT4-EGFP in resting, insulin ( $50 \mathrm{nmol} / \mathrm{L})$ stimulated, or insulin ( $50 \mathrm{nmol} / \mathrm{L})$ and dysidine $(20 \mu \mathrm{mol} / \mathrm{L})$ stimulated CHO-K1/GLUT4 cells is shown. The green fluorescence represents total exogenous GLUT4, and the red represents membrane-located GLUT4, indicated by an arrow. Scale bar, $10 \mu \mathrm{m}$. (C) Quantitative analysis of GLUT4-membrane translocation in CHO-K1/ GLUT4 cells. Serum-starved CHO-K1/GLUT4 cells were incubated with different concentrations of dysidine, or $20 \mu \mathrm{mol} / \mathrm{L}$ compound-2 (C2), or $20 \mu \mathrm{mol} / \mathrm{L}$ pervanadate (pervan) for $2 \mathrm{~h}$, and subsequently stimulated with $50 \mathrm{nmol} / \mathrm{L}$ insulin for $5 \mathrm{~min}$. The membrane-located GLUT4 level was represented by the intensity of red Cy5 fluorescence and normalized by the intensity of EGFP green fluorescence, which represented total GLUT4. The membrane-located GLUT4 level of the untreated cells is represented as "1". AU, artificial unit. ${ }^{b} P<0.05$, ${ }^{c} P<0.01 v s$ insulin treatment group. NS: no significant difference.

enhanced the insulin-stimulated membrane translocation of GLUT4 (Figures 5B and 5C).

In conclusion, dysidine alone activated the kinase cascade of the insulin pathway (Figure 4). Moreover, dysidine also sensitized insulin-stimulated AKT phosphorylation and GLUT4 translocation (Figure 5) in CHO-K1 cells.

Dysidine is a slow-binding PTPase inhibitor Given that dysidine can induce the phosphorylation of the insulin receptor and activate the downstream signaling pathway, it is possible that dysidine functions as an inhibitor of the protein tyrosine phosphatase (PTP) family. The PTP family can directly dephosphorylate IR and then negatively regulate the insulin signaling pathway ${ }^{[34]}$.

To support this hypothesis, an in vitro PTPase enzymatic system was constructed according to the published approach $^{[26]}$. As expected, dysidine exhibited potent inhibitory activity against PTP1B (Table S1 and Figure 6A), with an $\mathrm{IC}_{50}$ of $1.5 \mu \mathrm{mol} / \mathrm{L}$. To assay the selectivity of dysidine over other PTPs, a panel of PTPs was investigated, including PTP1B, TC-PTP, and CD $45^{[35]}$, and compound $-2^{[36]}$ was used as a positive control. Table $S 1$ shows the preference by dysidine for inhibition of PTP1B compared with other PTPs.

The mode of inhibition of PTP1B by dysidine was also investigated. During the assay, enzymatic reactions were initiated by the addition of PTP1B enzyme into mixtures containing $p$ NPP $(5 \mathrm{mmol} / \mathrm{L})$ and dysidine $(0.5-10 \mu \mathrm{mol} / \mathrm{L})$ or vehicle (DMSO). The hydrolysis of $p$ NPP by PTP1B was monitored in a continuous fashion. As shown in Figure 6B, the vehicle-treated reaction exhibited a simple linear progress curve, but in the presence of dysidine, the curves displayed a 

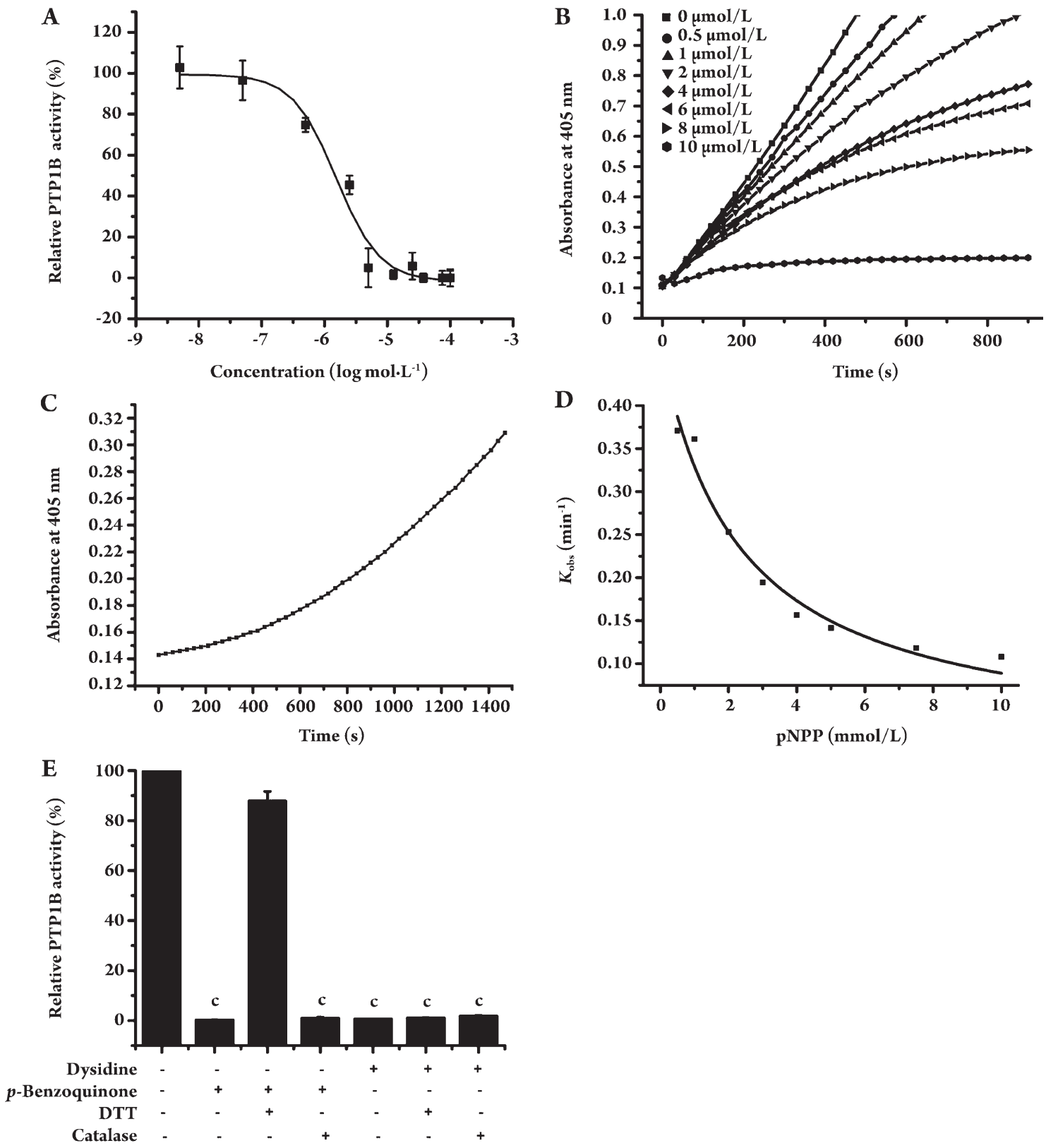

Figure 6. Dysidine is a reversible slow-binding PTP1B inhibitor. (A) Dysidine inhibited PTP1B activity in a dose-dependent manner. The PTP1B activity of a DMSO treated sample was represented as 100\%. (B) Dysidine inhibited PTP1B in a slow-binding feature. Different concentrations of dysidine were incubated with $5 \mathrm{mmol} / \mathrm{L} p \mathrm{NPP}$ for $10 \mathrm{~min}$., and reactions were initiated by addition of PTP1B. The absorbance at $405 \mathrm{~nm}$ was continuously detected every $30 \mathrm{~s}$. (C) The inhibition of dysidine against PTP1B was reversible. PTP1B $(1 \mu \mathrm{mol} / \mathrm{L})$ and dysidine $(150 \mu \mathrm{mol} / \mathrm{L})$ were incubated with each other at room temperature for $2 \mathrm{~h}$. Aliquots were then withdrawn and rapidly diluted into reaction buffer $(50 \mathrm{mmol} / \mathrm{L}$ HEPES, $1 \mathrm{mmol} / \mathrm{L}$ EDTA, $100 \mathrm{mmol} / \mathrm{L} \mathrm{NaCl}$ and $5 \mathrm{mmol} / \mathrm{L} p \mathrm{NPP}, \mathrm{pH} 5.0$ ) at a dilution ratio of 1:20. (D) Competition between dysidine and substrate for binding to PTP1B is shown. Reaction progress courses were initiated by the addition of PTP1B $(0.3 \mu \mathrm{mol} / \mathrm{L})$ to assay mixtures containing dysidine $(10 \mu \mathrm{mol} / \mathrm{L})$ and $p \mathrm{NPP}(0.5-10 \mathrm{mmol} / \mathrm{L})$. The $K_{\mathrm{obs}}$ values were obtained from fitting individual time courses as described in "Materials and methods". The solid line was fitted according to the equation: $K_{\mathrm{obs}}=K_{\max } /\left(1+[p \mathrm{NPP}] / K_{\mathrm{M}}\right)$. (E) Catalase and DTT had no effect on the inhibition of PTP1B by dysidine. PTP1B $(0.3 \mu \mathrm{mol} / \mathrm{L})$ was incubated with dysidine $(10 \mu \mathrm{mol} / \mathrm{L})$ or $p$-benzoquinone $(10 \mu \mathrm{mol} / \mathrm{L})$ in reaction buffer $(50 \mathrm{mmol} / \mathrm{L}$ HEPES, pH 5.0, $1 \mathrm{mmol} / \mathrm{L} \mathrm{EDTA}$, and $100 \mathrm{mmol} / \mathrm{L} \mathrm{NaCl})$ containing either catalase $(1000 \mathrm{U} / \mathrm{mL}), \mathrm{DTT}(5 \mathrm{mmol} / \mathrm{L})$, or neither of them, for $10 \mathrm{~min}$, and then $p \mathrm{NPP}(5 \mathrm{mmol} / \mathrm{L})$ was added to initiate reactions. The initial velocities were detected and the velocity of DMSO treated reaction was represented as $100 \%$. ${ }^{c} \mathrm{P}<0.01$ vs DMSO incubated group. 
quasi-linear relationship with time in the early part, converting later to a slower linear relationship. These reaction curves are typical progress curves for slow-binding inhibitors, suggesting that dysidine inhibited PTP1B in a slow-binding manner ${ }^{[37-40]}$. By considering the possibility that a slowbinding inhibitor might inhibit enzyme in an irreversible manner, the character of the reversibility or irreversibility of inhibition of PTP1B by dysidine was also inspected. For this purpose, PTP1B was preincubated with excess dysidine for $2 \mathrm{~h}$ and rapidly diluted into the reaction buffer (50 $\mathrm{mmol} / \mathrm{L}$ HEPES, $1 \mathrm{mmol} / \mathrm{L}$ EDTA, $100 \mathrm{mmol} / \mathrm{L} \mathrm{NaCl}$ and $5 \mathrm{mmol} / \mathrm{L} p \mathrm{NPP}, \mathrm{pH} 5.0$ ) at a dilution ratio of 1:20. The result shows a progress curve with time-dependent recovery of PTP1B enzymatic activity, implying that the inhibition of dysidine against PTP1B is reversible (Figure 6C).

In order to determine whether dysidine was PTP1B active-site directed, its competition with substrate was determined by measuring $K_{o b s}$, the pseudo-first order rate constant for the onset of inhibition, from progress curves obtained at constant inhibitor concentrations (dysidine, $10 \mu \mathrm{mol} / \mathrm{L}$ ) but with varying $p$ NPP concentrations $(0.5-10 \mathrm{mmol} / \mathrm{L})$. As shown in Figure 6D, there are clearly inverse correlations between $K_{o b s}$ and $p$ NPP concentration, as would be expected from competitive binding between dysidine and $p$ NPP.

Quinone-containing compounds were reported to inhibit many cysteine-containing enzymes in a nonspecific manner. Covalent addition ${ }^{[41,42]}$ and irreversible oxidation ${ }^{[43]}$ of cysteine in the active site are the main mechanisms. Since $p$-benzoquinone was contained in the structure of the three sesquiterpene quinones, the inhibition of dysidine against PTP1B was measured in the presence of either DTT (5 $\mathrm{mmol} / \mathrm{L})$ or catalase $(1000 \mathrm{U} / \mathrm{mL})$ to investigate whether these quinone-dependent mechanisms were involved. $p$-Benzoquinone was used as a control. As indicated in Figure 6E and Table S2, the $\mathrm{IC}_{50}$ values of dysidine with or without the presence of $5 \mathrm{mmol} / \mathrm{L}$ DTT were almost the same, while the presence of DTT greatly alleviated the inhibitory activity of $p$-benzoquinone. Catalase had no effect on the inhibition by either dysidine $(10 \mu \mathrm{mol} / \mathrm{L})$ or $p$-benzoquinone $(10$ $\mu \mathrm{mol} / \mathrm{L})$. These results indicated that in our enzymatic system, dysidine and $p$-benzoquinone inhibited PTP1B via different mechanisms. Covalent addition to the cysteine in the active site may account for inhibition by $p$-benzoquinone, whereas the inhibition by dysidine did not depend on either the irreversible oxidation or covalent addition of quinone.

\section{Discussion}

The sesquiterpene hydroquinones/quinones, which are a class of marine sponge metabolites with abundant structural variants and biological activities, have been extensively investigated. Several sesquiterpene hydroquinones/quinones have been shown to have numerous biological functions, including anti-tumor ${ }^{[1-3]}$, anti-HIV ${ }^{[4]}$, and anti-inflammatory activities $^{[5,6]}$, among others ${ }^{[7]}$. However, its anti-diabetic effect has not yet been reported. In the current work, one sesquiterpene quinone derivative, dysidine, was isolated from the Hainan sponge Dysidea villosa from the Chinese South Sea, and the effects of dysidine on the insulin signaling pathway were investigated.

Impaired glucose uptake in peripheral tissues is the major mechanism of type 2 diabetes. Therefore, fully differentiated 3T3-L1 adipocytes were employed to probe the potential effect of dysidine on the promotion of glucose uptake. We found that dysidine could greatly promote glucose uptake in 3T3-L1 cells. In an effort to investigate the underlying mechanism, the cellular distribution of GLUT4 was investigated. Our results show that both the endogenous GLUT4 in 3T3-L1 cells and the exogenous GLUT4-EGFP in CHO-K1/GLUT4 cells were translocated to the cell membrane in simulation with dysidine, thus indicating the involvement of GLUT4 in the promotion of glucose uptake by dysidine. Further investigation of the upstream signaling pathway revealed that dysidine activated the proximal insulin receptor signaling events, including the phosphorylation of IR. It is known that IR and IRS1 can be dephosphorylated by several PTPases, including PTP1B, PTP $\alpha$, LAR, CD45, TC-PTP, and others ${ }^{[35]}$. Therefore, the ability of dysidine to inhibit PTPases was tested in vitro, and, as expected, dysidine was shown to be a potent PTP1B inhibitor with moderate selectivity against TCPTP and CD45. In conclusion, dysidine exhibited potent activity in the promotion of glucose uptake in 3T3-L1 cells, and inhibition of PTPases might be the underlying mechanism. However, we noticed that dysidine increased glucose uptake to a level equivalent to that induced by insulin. This is inconsistent with the fact that IR, AKT and GLUT4 were less activated by dysidine than by insulin. Therefore, some additional pathways might be involved in the promotion of glucose uptake by dysidine in 3T3-L1 cells. We found that dysidine also increased the phosphorylation of p38 MAPK in 3T3-L1 cells. Since p38 MAPK has been proven to increase GLUT4 activity independently of GLUT4 translocation, the activation of p38 MAPK by dysidine is probably the additional pathway that is responsible for the promotion of glucose uptake by dysidine ${ }^{[44,45]}$.

Dysidine was reported as a phospholipase A2 (PLA2) inhibitor with an $\mathrm{IC}_{50}$ value of $2 \mu \mathrm{mol} / \mathrm{L}^{[6]}$. Since PLA2 
mainly hydrolyzes phospholipids and releases arachidonic $\operatorname{acid}^{[46]}$, which is a precursor of inflammatory mediators, the activation of the insulin pathway by dysidine might not involve the inhibition of PLA2.

The quinone-containing compounds have been reported to inhibit PTPs through different mechanisms. For example, a number of ortho-quinone-containing compounds inhibited PTP $\alpha$ in a catalase-sensitive manner ${ }^{[43]}$, suggesting that these compounds inhibited PTPa via generation of ROS (including $\mathrm{H}_{2} \mathrm{O}_{2}$ ) and subsequent oxidation of cysteine in the active site. Moreover, menadione (vitamin K3 $)^{[41]}$ and other vitamin $\mathrm{K}$ analogues ${ }^{[42]}$ containing a benzoquinone in their structure were reported to inhibit the CDC25 phosphatase by covalent interaction between the compound and the enzyme. This covalent bond can be blocked by DTT, GSH or other thiol-containing reductants. The Michael addition between quinone and the thiol in cysteine was proposed to be the underlying mechanism. In addition to the covalent modification of the active site in PTPs, quinone-containing compounds also inhibit PTPs in a competitive and reversible manner ${ }^{[47]}$. In the current work, we showed that dysidine inhibited PTP1B without either irreversible oxidation or the covalent addition of the quinone (Figure 6E and Table S2). First, catalase (up to $1000 \mathrm{U} / \mathrm{mL}$ ), which was demonstrated to be active in our PTP1B reaction buffer (data not show), had no effect on the inhibition of dysidine, suggesting that ROS were not involved in the inhibition by dysidine. Secondly, $5 \mathrm{mmol} / \mathrm{L}$ DTT almost completely reversed the inhibition of $p$-benzoquinone but did not affect that of dysidine. This indicates that $p$-benzoquinone might inhibit PTP1B via covalent modification of the cysteine in the active site, but that dysidine does not undergo that kind of addition. In summary, the inhibition of PTP1B by dysidine did not rely on the oxidation or the covalent addition of the quinone.

Slow-binding inhibitors bind slowly to enzymes on the time scale of enzyme turnover, thus displaying gradually decreased velocities with time. Thus, these inhibitors are also known as time-dependent inhibitors. Several PTP1B inhibitors were reported to function in a slow-binding mode ${ }^{[38,40]}$. In the current work, dysidine was also demonstrated to be a slow-binding inhibitor. In our in vitro enzymatic system, when the reaction was initialized by the addition of PTP1B, the reaction velocity of the DMSO reaction was stable, as indicated by a linear curve, while the velocities of the treated reactions decreased over time in the early part of the curve and reached steady state later (Figure 6B), indicating a slowbinding mode. Moreover, the slow binding of dysidine was further confirmed by a dilution assay (Figure 6C). When the mixture of dysidine and PTP1B was diluted in a substratecontaining buffer, the reaction curve displayed a shallow slope at first and eventually turned over to steady state due to the slow off-rate of dysidine. The time-dependent recovery of PTP1B activity in the dilution assay also indicated that the inhibition by dysidine was reversible. Furthermore, dysidine was shown to be PTP1B active-site directed, as indicated by the inverse correlations between the $K_{o b s}$ and the $p \mathrm{NPP}$ concentration. Slow-binding inhibitors are expected to exhibit clinical advantages over rapidly reversible inhibitors owing to their binding of the target for a significant time period ${ }^{[48]}$. Since dysidine was determined to be a slow-binding inhibitor according to its slow-on and slow-off affinity rates (Figure $6 \mathrm{~B}$ and $6 \mathrm{C}$ ), this intrinsic characteristic should be a benefit to its potential usage as a lead compound.

Together with our previous findings ${ }^{[26]}$, it is expected that our work will provide useful information for understanding the relevant biological functions of the sesquiterpene hydroquinones/quinones from the sponge Dysidea villosa. Moreover, dysidine might be used as a potential lead compound for anti-diabetes therapeutic agent discovery.

\section{Acknowledgements}

We are very grateful to Prof Nicholas K TONKS (Cold Spring Harbor Laboratory, NY, USA) for supplying the TC45 vector, to Prof Rafael PULIDO (Centro de Investigación Príncipe Felipe, Valencia 46013, Spain) for providing the pGEX2T-CD45 (aa 560-1256), to Prof Frank R JIRIK (University of British Columbia, Vancouver, British Columbia V5Z 4H4, Canada) for providing the pGEX2T-PTPa vector, and to Prof Yan CHEN (Institute of Nutritional Sciences, Shanghai, China) for supplying the 3T3-L1 cell.

This work was supported by the State Key Program of Basic Research of China (grants 2004CB518905 and 2007CB914304), the National Natural Science Foundation of China (grants 30525024, 90713046, 20721003, and 20772136), and Foundation of Chinese Academy of Sciences (grant KSCX2-YW-R-18).

\section{Author contribution}

Prof Xu SHEN, Prof Hua-liang JIANG and Prof Yue-wei GUO designed the research. Yu ZHANG performed the research, analyzed data and wrote the paper, and Yan LI isolated dysidine. 
Table S1. Selectivity of dysidine against a panel of PTPs.

\begin{tabular}{lcc}
\hline \multirow{2}{*}{ PTPs } & \multicolumn{2}{c}{$\mathrm{IC}_{50}(\mu \mathrm{mol} / \mathrm{L})$} \\
\hline PTP1B & Compound-2 \\
TC-PTP & $1.5 \pm 0.4$ & $1.2 \pm 0.2$ \\
CD45 & $4.2 \pm 0.3$ & $4.3 \pm 0.4$ \\
& $7.6 \pm 1.3$ & $8.3 \pm 0.1$ \\
\hline
\end{tabular}

Table S2. DTT had no effect on the inhibition of PTP1B by dysidine.

\begin{tabular}{lcc}
\hline \multirow{2}{*}{ Compounds } & \multicolumn{2}{c}{$\mathrm{IC}_{50}(\mu \mathrm{mol} / \mathrm{L})$} \\
& Without DTT & $5 \mathrm{mmol} / \mathrm{L} \mathrm{DTT}$ \\
\hline Dysidine & $1.5 \pm 0.4$ & $1.1 \pm 0.1$ \\
p-Benzoquinone & $1.4 \pm 0.1$ & $38.9 \pm 5.2$ \\
\hline
\end{tabular}

\section{References}

1 Muller WE, Sladic D, Zahn RK, Bassler KH, Dogovic N, Gerner H, et al. Avarol-induced DNA strand breakage in vitro and in Friend erythroleukemia cells. Cancer Res 1987; 47: 6565-71.

2 Muller WE, Dogovic N, Zahn RK, Maidhof A, Diehl-Seifert B, Becker $\mathrm{C}$, et al. Inhibition of mitosis by avarol, a natural product isolated from the sponge Dysidea avara. Basic Appl Histochem 1985; 29: 321-30.

3 Yoo HDL, Sanghara D, Daley J, van Soest D, Andersen R, Isoarenarol RJ. A new protein kinase inhibitor from the marine sponge Dysidea arenaria. Pharm Biol 2003; 41: 223-5.

4 Sarin PS, Sun D, Thornton A, Muller WE. Inhibition of replication of the etiologic agent of acquired immune deficiency syndrome (human T-lymphotropic retrovirus/lymphadenopathy-associated virus) by avarol and avarone. J Natl Cancer Inst 1987; 78: 663-6.

5 Lucas R, Giannini C, D'Auria MV, Paya M. Modulatory effect of bolinaquinone, a marine sesquiterpenoid, on acute and chronic inflammatory processes. J Pharmacol Exp Ther 2003; 304: 117280.

6 Giannini C, Debitus C, Lucas R, Ubeda A, Paya M, Hooper JN, et al. New sesquiterpene derivatives from the sponge Dysidea species with a selective inhibitor profile against human phospholipase A2 and other leukocyte functions. J Nat Prod 2001; 64: 612-5.

7 Sipkema D, Franssen MC, Osinga R, Tramper J, Wijffels RH. Marine sponges as pharmacy. Mar Biotechnol (NY) 2005; 7 : 142-62.

8 Proksch P, Edrada RA, Ebel R. Drugs from the seas - current status and microbiological implications. Appl Microbiol Biotechnol 2002; 59: 125-34.

9 Warram JH, Martin BC, Krolewski AS, Soeldner JS, Kahn CR. Slow glucose removal rate and hyperinsulinemia precede the development of type II diabetes in the offspring of diabetic parents. Ann Intern Med 1990; 113: 909-15.

10 Haffner SM, Stern MP, Dunn J, Mobley M, Blackwell J, Bergman RN. Diminished insulin sensitivity and increased insulin response in nonobese, nondiabetic Mexican Americans. Metabolism 1990;
39: 842-7.

11 DeFronzo RA. Lilly lecture 1987. The triumvirate: beta-cell, muscle, liver. A collusion responsible for NIDDM. Diabetes 1988; 37: 667-87.

12 Saltiel AR, Kahn CR. Insulin signalling and the regulation of glucose and lipid metabolism. Nature 2001; 414: 799-806.

13 Huang S, Czech MP. The GLUT4 glucose transporter. Cell Metab 2007; 5: 237-52.

14 Goldstein BJ, Bittner-Kowalczyk A, White MF, Harbeck M. Tyrosine dephosphorylation and deactivation of insulin receptor substrate- 1 by protein-tyrosine phosphatase 1B. Possible facilitation by the formation of a ternary complex with the Grb2 adaptor protein. J Biol Chem 2000; 275: 4283-9.

15 Ahmad F, Li PM, Meyerovitch J, Goldstein BJ. Osmotic loading of neutralizing antibodies demonstrates a role for protein-tyrosine phosphatase $1 \mathrm{~B}$ in negative regulation of the insulin action pathway. J Biol Chem 1995; 270: 20503-8.

16 Byon JC, Kusari AB, Kusari J. Protein-tyrosine phosphatase-1B acts as a negative regulator of insulin signal transduction. Mol Cell Biochem 1998; 182: 101-8.

17 Cheng A, Uetani N, Simoncic PD, Chaubey VP, Lee-Loy A, McGlade CJ, et al. Attenuation of leptin action and regulation of obesity by protein tyrosine phosphatase 1B. Dev Cell 2002; 2: 497-503.

18 Bence KK, Delibegovic M, Xue B, Gorgun CZ, Hotamisligil GS, Neel BG, et al. Neuronal PTP1B regulates body weight, adiposity and leptin action. Nat Med 2006; 12: 917-24.

19 Elchebly M, Payette P, Michaliszyn E, Cromlish W, Collins S, Loy $\mathrm{AL}$, et al. Increased insulin sensitivity and obesity resistance in mice lacking the protein tyrosine phosphatase-1B gene. Science 1999; 283: 1544-8.

20 Klaman LD, Boss O, Peroni OD, Kim JK, Martino JL, Zabolotny $\mathrm{JM}$, et al. Increased energy expenditure, decreased adiposity, and tissue-specific insulin sensitivity in protein-tyrosine phosphatase 1B-deficient mice. Mol Cell Biol 2000; 20: 5479-89.

21 Zinker BA, Rondinone CM, Trevillyan JM, Gum RJ, Clampit JE, Waring JF, et al. PTP1B antisense oligonucleotide lowers PTP1B protein, normalizes blood glucose, and improves insulin sensitivity in diabetic mice. Proc Natl Acad Sci USA 2002; 99: 11357-62.

22 Liu G. Technology evaluation: ISIS-113715, Isis. Curr Opin Mol Ther 2004; 6: 331-6.

23 Cheon HG, Kim SM, Yang SD, Ha JD, Choi JK. Discovery of a novel protein tyrosine phosphatase-1B inhibitor, KR61639: potential development as an antihyperglycemic agent. Eur J Pharmacol 2004; 485: 333-9.

24 Dufresne C, Roy P, Wang Z, Asante-Appiah E, Cromlish W, Boie Y, et al. The development of potent non-peptidic PTP-1B inhibitors. Bioorg Med Chem Lett 2004; 14: 1039-42.

25 Arner P. The adipocyte in insulin resistance: key molecules and the impact of the thiazolidinediones. Trends Endocrinol Metab 2003; 14: 137-45.

26 Sun T, Wang Q, Yu Z, Zhang Y, Guo Y, Chen K, et al. Hyrtiosal, a PTP1B inhibitor from the marine sponge Hyrtios erectus, shows extensive cellular effects on PI3K/AKT activation, glucose transport, and TGFbeta/Smad2 signaling. Chembiochem 2007; 8: 187-93.

27 Copeland RA. Enzymes: a practical introduction to structure, mechanism, and data analysis. New York: A John Wiley \& Sons, 
Inc; 2000.

28 Furuhashi M, Tuncman G, Gorgun CZ, Makowski L, Atsumi G, Vaillancourt E, et al. Treatment of diabetes and atherosclerosis by inhibiting fatty-acid-binding protein aP2. Nature 2007; 447: 959-65.

29 Bogan JS, McKee AE, Lodish HF. Insulin-responsive compartments containing GLUT4 in 3T3-L1 and CHO cells: regulation by amino acid concentrations. Mol Cell Biol 2001; 21: 4785-806.

30 Lampson MA, Racz A, Cushman SW, McGraw TE. Demonstration of insulin-responsive trafficking of GLUT4 and vpTR in fibroblasts. J Cell Sci 2000; 113 ( Pt 22): 4065-76.

31 Sano H, Eguez L, Teruel MN, Fukuda M, Chuang TD, Chavez $\mathrm{JA}$, et al. Rab10, a target of the AS160 Rab GAP, is required for insulin-stimulated translocation of GLUT4 to the adipocyte plasma membrane. Cell Metab 2007; 5: 293-303.

32 Nugent C, Prins JB, Whitehead JP, Wentworth JM, Chatterjee VK, O'Rahilly S. Arachidonic acid stimulates glucose uptake in 3T3-L1 adipocytes by increasing GLUT1 and GLUT4 levels at the plasma membrane. Evidence for involvement of lipoxygenase metabolites and peroxisome proliferator-activated receptor gamma. J Biol Chem 2001; 276: 9149-57.

33 Wu-Wong JR, Berg CE, Wang J, Chiou WJ, Fissel B. Endothelin stimulates glucose uptake and GLUT4 translocation via activation of endothelin $\mathrm{ET}_{\mathrm{A}}$ receptor in 3T3-L1 adipocytes. J Biol Chem 1999; 274: 8103-10.

34 Goldstein BJ, Ahmad F, Ding W, Li PM, Zhang WR. Regulation of the insulin signalling pathway by cellular protein-tyrosine phosphatases. Mol Cell Biochem 1998; 182: 91-9.

35 Stoker AW. Protein tyrosine phosphatases and signalling. J Endocrinol 2005; 185: 19-33.

36 Wiesmann C, Barr KJ, Kung J, Zhu J, Erlanson DA, Shen W, et al. Allosteric inhibition of protein tyrosine phosphatase 1B. Nat Struct Mol Biol 2004; 11: 730-7.

37 Morrison JF, Walsh CT. The behavior and significance of slowbinding enzyme inhibitors. Adv Enzymol Relat Areas Mol Biol 1988; 61: 201-301.

38 Park J, Pei D. Trans-beta-nitrostyrene derivatives as slow-binding inhibitors of protein tyrosine phosphatases. Biochemistry 2004;
43: 15014-21.

39 Shim YS, Kim KC, Lee KA, Shrestha S, Lee KH, Kim CK, et al. Formylchromone derivatives as irreversible and selective inhibitors of human protein tyrosine phosphatase 1B. Kinetic and modeling studies. Bioorg Med Chem 2005; 13: 1325-32.

40 Fu H, Park J, Pei D. Peptidyl aldehydes as reversible covalent inhibitors of protein tyrosine phosphatases. Biochemistry 2002; 41: 10700-9.

41 Seung Wook Ham HJP, Lim DH. Studies on menadione as an inhibitor of the cdc25 phosphatase. Bioorg Chem 1997; 25: 33-6.

42 Kar S, Lefterov IM, Wang M, Lazo JS, Scott CN, Wilcox CS, et al. Binding and inhibition of $\mathrm{Cdc} 25$ phosphatases by vitamin $\mathrm{K}$ analogues. Biochemistry 2003; 42: 10490-7.

43 Bova MP, Mattson MN, Vasile S, Tam D, Holsinger L, Bremer M, et al. The oxidative mechanism of action of ortho-quinone inhibitors of protein-tyrosine phosphatase alpha is mediated by hydrogen peroxide. Arch Biochem Biophys 2004; 429: 30-41.

44 Bazuine M, Carlotti F, Rabelink MJ, Vellinga J, Hoeben RC, Maassen JA. The p38 mitogen-activated protein kinase inhibitor SB203580 reduces glucose turnover by the glucose transporter- 4 of 3T3-L1 adipocytes in the insulin-stimulated state. Endocrinology 2005; 146: 1818-24.

45 Somwar R, Koterski S, Sweeney G, Sciotti R, Djuric S, Berg C, et al. A dominant-negative p38 MAPK mutant and novel selective inhibitors of p38 MAPK reduce insulin-stimulated glucose uptake in 3T3-L1 adipocytes without affecting GLUT4 translocation. J Biol Chem 2002; 277: 50386-95.

46 Balsinde J, Balboa MA, Insel PA, Dennis EA. Regulation and inhibition of phospholipase A2. Annu Rev Pharmacol Toxicol 1999; 39: 175-89.

47 Brisson M, Nguyen T, Vogt A, Yalowich J, Giorgianni A, Tobi $\mathrm{D}$, et al. Discovery and characterization of novel small molecule inhibitors of human Cdc25B dual specificity phosphatase. Mol Pharmacol 2004; 66: 824-33.

48 Copeland RA. Evaluation of enzyme inhibitors in drug discovery: a guide for medicinal chemists and pharmacologists. Hoboken, New Jersey: John Wiley \& Sons, Inc; 2005. 